\title{
Metabolite Fingerprintiing of Eleutherine palmifolia (L.) Merr. by HPTLC-Densitometry and Its Correlation with Anticancer Activities and In Vitro Toxicity
}

Roihatul Mutiah', Chorida Muhjatul Hadya1, Burhan Ma'arif Z.A. 1, Weka Sidha Bhagawan', Rahmi Annisa', Yen Yen Ari Indrawijaya' ${ }^{1}$, Fadhila Isma Huwaida', Ria Ramadhani D.A. ${ }^{1}$, Retno Susilowati ${ }^{2}$, Imam Taufik ${ }^{3 *}$

1. Department of Pharmacy, Faculty of Medical and Health Science, State Islamic University of Maulana Malik Ibrahim, Jl Gajayana No 50, Malang, Jawa Timur 65115 Idonesia

2. Department of Biology, Faculty of Science and Technology, State Islamic University of Maulana Malik Ibrahim Malang, Jl Gajayana No 50, Malang, Jawa Timur 65115 Idonesia

3. Indonesia National Agency of Drug and Food Control, Jl Dr. Kayadoe, Ambon Maluku 97116 Indonesia

\section{Info Article}

Submitted: $14-01-2019$

Revised: $10-06-2019$

Accepted: $18-06-2019$

*Corresponding author Imam Taufik

Email:

imam.taufik-

2014@ff.unair.ac.id

\section{ABSTRACT}

Eleutherine palmifolia (L.) Merr. (E. palmifolia or Dayak Onion) is an anticancer plant used for traditional medicines. The difference of cultivation sites may affect metabolites content, pharmacological activity and toxicity profiles. This study aimed to determine the metabolite fingerprinting, anticancer and toxicity profiles of E. palmifolia from several regions in Indonesia for authentication, efficacy, safety and quality control. Samples were obtained from six different locations in Indonesia which included West Java (WJ), Central Java (CJ), East Java (EJ), East Borneo (EB), Central Borneo (CB), and South Borneo (SB). Metabolite fingerprinting was determined by HPTLC-densitometry method and profile of anticancer and toxicity were analyzed by MTT-ELISA method. The difference among metabolite fingerprinting, anticancer, and toxicity profile was analyzed by Principal Component Analysis (PCA) and Hierarchical Component Analysis (HCA), whereas the association among them was analyzed by Partial Least Square (PLS). The PCA results showed a difference in E. palmifolia metabolite fingerprints and the HCA results showed that six different regions were the same cluster. The PLS-DA analysis showed four significant metabolites proposed as anticancer markers with Rf $0.34,0.59,0.76,0.93$ and three significant metabolites proposed as negative markers with Rf $0.02,0.44$ and 0.59 . E. palmifolia from East Java had the lowest $\mathrm{IC}_{50}(86.98 \pm 4.62 \mu \mathrm{g} / \mathrm{mL})$ and higher SI value (5.5).

Keywords: E. palmifolia, metabolite fingerprinting, anticancer profiles, toxicity profiles

\section{INTRODUCTION}

E. palmifolia (Dayak Onion) has been used empirically by Indonesian people to treat several diseases such as cancer. E. palmifolia bulb contains glycosides, flavonoids, steroids, tannins, and phenolics compounds. The flavonoids contained are considered responsible for the anticancer activity through inhibition of the colon cancer cell cycle in the G1/S and G2/M phases (Ren et al., 2003; Chahar et al., 2011). Eluetherine and elecanacin compounds in this plant are also known to inhibit $\mathrm{TCF} / \beta$-catenin transcription in SW480 colon cancer cells (Li et al., 2008) and to show selective activity against colorectal cancer (Fitri et al., 2014).

Differences in cultivation sites may affect metabolite content, activity, and toxicity (Verma and Shukla, 2015) including internal and external factors (Kim et al., 2011). Internal factors include genetic factors and physiological variations (Verma and Shukla, 2015), whereas external factors (environment) include climate change, soil type, nutrient content, fertilizer use, damage caused by microorganisms, stress induced by UV radiation, heavy metals, and pesticides (Canas et al., 2015). 
Table I. Origin of samples

\begin{tabular}{clccccc}
\hline Sample & Sites of Cultivation & $\begin{array}{c}\text { Altitude } \\
(\mathbf{m})\end{array}$ & $\begin{array}{c}\text { Average } \\
\text { Temp }\left({ }^{\mathbf{o}} \mathbf{C}\right)\end{array}$ & $\begin{array}{c}\text { Average } \\
\text { Rainfall (mm) }\end{array}$ & $\begin{array}{c}\text { Climate } \\
\text { Type }\end{array}$ & Voucher Number \\
\hline EB & East Borneo & 29 & 26.4 & 2376 & Af & $074 / 348 / 102.7 / 2017$ \\
SB & South Borneo & 10 & 26.8 & 2765 & Af & $074 / 348 / 102.7 / 2017$ \\
CB & Central Borneo & 31 & 27.2 & 2627 & Af & $074 / 348 / 102.7 / 2017$ \\
EJ & East Java & 127 & 25.0 & 1819 & Aw & $074 / 348 / 102.7 / 2017$ \\
WJ & West Java & 668 & 24.0 & 3454 & Af & $074 / 348 / 102.7 / 2017$ \\
CJ & Central Java & 1221 & 19.1 & 3299 & Am & $074 / 348 / 102.7 / 2017$ \\
\hline
\end{tabular}

Metabolite fingerprinting of medicinal plants is very important to ensure authenticity, safety, and efficacy because of varying metabolite content (Patel et al., 2015). Metabolite fingerprinting is an analytical technique based on the chromatogram pattern of compounds that provide special characteristics (Wolfender et al., 2015, Fiehn, 2002). HPTLC can be an alternative for analyzing plant extracts because it is more efficient in evaluating herbal medicines (Dhalwal et al., 2008). To develop E. palmifolia into phytomedicine, several requirements must be met. Phytomedicine is a preparation of natural ingredients in which efficacy and safety has been proven scientifically with clinical trials and pre-clinical trials along with in which raw materials and end-products has been standardized (Indonesia National Agency of Drug and Food Control, 2005). Until now, there is still no report on metabolite fingerprinting of E. palmifolia from Indonesia. In this work, HPTLC and ELISA were used to determine metabolite profiles, anticancer activity, and toxicity profiles of E. palmifolia to obtain marker compounds, efficacy, and safety profiles of this plant.

\section{MATERIALS AND METHODS}

\section{Plant material and extraction}

E. palmifolia was obtained from West Java, Central Java, East Java, East Borneo, Central Borneo, and South Borneo (Table I). The specimens were determined at the UPTD Materia Medika Malang with collection number $074 / 348 / 102.7 / 2017$ and were stored in the Pharmacognosy Laboratory of Pharmacy Department of State Islamic University of Maulana Malik Ibrahim Malang. Simplicial powder was extracted by UAE method using $96 \%$ ethanol with a ratio of 1:20. The ethanol extract was stored in an oven at $40^{\circ} \mathrm{C}$ and was ready to use for further testing.

\section{Mobile phase optimization}

Ten mg of E. palmifolia $96 \%$ ethanol extract was dissolved in $1 \mathrm{~mL}$ of $96 \%$ ethanol. The $2 \mu \mathrm{L}$ of extract was applied on the $20 \times 10 \mathrm{~cm} \mathrm{~F}_{254}$ Silica Gel HPTLC plate and was eluted using 2 types of mobile phases i.e. chloroform: methanol $(8: 2 \mathrm{v} / \mathrm{v})$ and $\mathrm{n}$ hexane:ethyl acetate $(6: 4 \mathrm{v} / \mathrm{v})$. HPTLC plate results were scanned by TLC Scanner (CAMAG, Germany) at $254 \mathrm{~nm}$ and $366 \mathrm{~nm}$, were sprayed with $10 \%$ $\mathrm{H}_{2} \mathrm{SO}_{4}$ as its stainer and were heated on the hot plate (CAMAG, Germany) at $105^{\circ} \mathrm{C}$ for $5 \mathrm{~min}$.

\section{Method validation}

The validation method for metabolite fingerprinting was carried out using two parameters including precision and stability test (on a Merck HPTLC plate). Precision and stability tests were carried out by applying $5 \mu \mathrm{L}$ of samples on a plate (concentrations of 20.000 and $10.000 \mathrm{ppm}$ ) at $0,15,30,45,60,75$ and $90 \mathrm{~min}$ by 3 times replication. Precision test (interday) and stability test (on the plate) were analyzed using PCA (Indah, 2015).

\section{Metabolite fingerprinting test}

Each ten mg of $96 \%$ ethanol extract of $\mathrm{E}$. palmifolia from six different locations including West Java (WJ), Central Java (CJ), East Java (EJ), East Borneo (EB), Central Borneo (CB) and South Borneo (SB) was dissolved in 96\% ethanol to obtain concentration of $20.000 \mathrm{ppm}$ and $10.000 \mathrm{ppm}$, was filtered using a membrane filter of $0.20 \mu \mathrm{m}$. Five $\mu \mathrm{L}$ of samples was applied $(10.000$ ppm) on a $20 \times 10 \mathrm{~cm} \mathrm{~F}_{254}$ Silica Gel HPTLC plate and was eluted using selected mobile phase (chloroform:methanol 80:20 v/v) and 3 times replication, was sprayed using $10 \%$ sulfuric acid solution, and HPTLC plate was scanned using TLC Scanner (CAMAG, Germany) at $254 \mathrm{~nm}$. All spots on all tracks were scanned at $200-700 \mathrm{~nm}$ and were 
visualized using TLC Visualizer (CAMAG, Germany) (Taufik, 2017).

\section{Anticancer activity and toxicity test using the MTT method Cell culture}

Cells were taken from a liquid nitrogen tank at $-80^{\circ} \mathrm{C}$ and were thawed at $37^{\circ} \mathrm{C}$. Subsequently, the cells were transferred to a conical tube containing 1640 serum RPMI media for WiDr cancer cells and M199 for normal cells. Cells were centrifuged to separate the pellets from the supernatant. The supernatant was discarded, and the procedure was repeated twice. One $\mathrm{mL}$ of $10 \%$ FBS solvent was added and was resuspended until homogeneous. Cells were transferred to a culture flask and were incubated in an incubator at $37^{\circ} \mathrm{C}$ $5 \% \mathrm{CO}_{2}$ for $2 \times 24$ hours. The media was replaced continuously, and the number of live cells was checked regularly (Mutiah, 2017).

\section{Cytotoxicity test using MTT assay method}

Cells were calculated in a hemocytometer and were diluted to a certain density i.e. $174.25 \times 104$ cells for WiDr cells and $74.75 \times 104$ cells for Vero cells. Each cell was transferred into a-96 well plate by $100 \mu \mathrm{L} /$ well and was incubated in a $5 \% \mathrm{CO}_{2}$ incubator at $37^{\circ} \mathrm{C}$ for $24 \mathrm{~h}$. After $24 \mathrm{~h}$, the media on the plate was discarded. A number of $96 \%$ ethanol extract of E. palmifolia $\mathrm{L}$ with a certain weight was diluted in a $1 \% \mathrm{v} / \mathrm{v}$ DMSO to make concentration $(\mu \mathrm{g} / \mathrm{mL})$ of $500 ; 250 ; 125 ; 62.5$; 31.25; 15.625 and 7.625 for WiDr cells and concentration $(\mu \mathrm{g} / \mathrm{mL})$ of $1000 ; 500 ; 250 ; 125$; $62.5 ; 31.25 ; 15,625$ for vero cells, was transferred to well three times replication, and was incubated for $24 \mathrm{~h}$ at $37^{\circ} \mathrm{C}$ and $5 \% \mathrm{CO}_{2}$. After incubation, the media was discarded and was replaced with $100 \mu \mathrm{L} /$ well of MTT reagent, was incubated for $3 \mathrm{~h}$. If formazan had been formed, it was added a $100 \mu \mathrm{L} /$ well of $10 \%$ SDS in $0.1 \mathrm{~N} \mathrm{HCl}$, was incubated in a dark room or was covered with aluminum foil for $24 \mathrm{~h}$ at room temperature, and had its absorbance measured by ELISA reader at $590 \mathrm{~nm}$ (Mutiah, 2017).

\section{Cytotoxicity analysis}

The absorbance data obtained from each well were converted to percentage of cell viability using equation:

Percentage of cell viability $(\%)=$

(abs. treatment - abs. media control)

$\overline{\text { (abs. cell control - abs. media control) }}$
The percentage of cell viability was calculated to get $\mathrm{IC}_{50}$ value. $\mathrm{IC}_{50}$ is a concentration in which $50 \%$ of population cell growth is inhibited reflecting the cytotoxic potential of an extract (Mutiah, 2017). IC 50 values were determined by probit analysis using SPSS v25.

\section{Analysis of Metabolite Fingerprinting Data}

Metabolite fingerprinting data of $E$. palmifolia ethanol extract from each location (Rf value, AUC, maximum absorbance) were identified and were processed using PCA and HCA (Multibase v2015 adds in Excel v2013) to obtain the difference among them, whereas the anticancer profile of WiDr cells and Vero cells were processed using one-way ANOVA (SPSS v16).

\section{RESULT AND DISCUSSION Method validation}

The validation method was carried out before the metabolite fingerprint of E. palmifolia extract were tested to determine whether the analysis method used in this study had met the requirements in the validation parameters i.e. stability test after it was applied on HPTLC plates and interday precision tests (Indah, 2015).

\section{Precision testing}

The precision test aimed to obtain the proximity of measurement results when the analysis method was repeated (Ravichandran et al. 2010). The results obtained showed that samples with a concentration of $10.000 \mathrm{ppm}$ were more precise than those with concentrations of $20.000 \mathrm{ppm}$. The profile of PCA analysis for a precision test (Figure 1) showed that the repetition at the concentration of $10.000 \mathrm{ppm}$ was more precise than the concentration of $20.000 \mathrm{ppm}$. This result was used to determine which concentration was best to be chosen for metabolite fingerprinting testing.

\section{Stability test}

The stability test is a stage of pre-validation to show sufficient stability of an analyte in a matrix or on an HPTLC plate in a certain time. This stage is the most important stage in conducting research (Yuwono and Indriyanto, 2005). Stability test of E. palmifolia extract on HPTLC plate was carried out in minutes $0,15,30,45,60,75$ and 90 . The results of the stability test showed that analyte could be well separated and stable until $90 \mathrm{~min}$ on the HPTLC plate (Figure 2). 


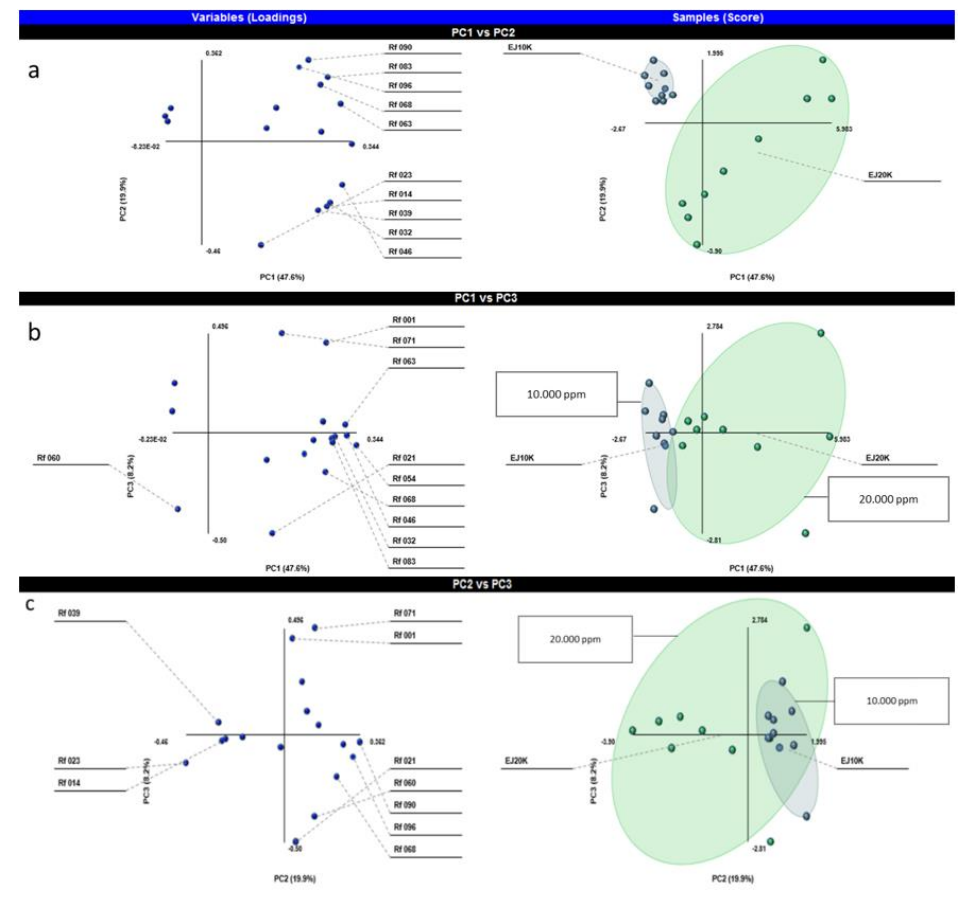

Figure 1. PCA profile (in principal component/PC) for precision test (on HPTLC plate) between concentration $10.000 \mathrm{ppm}$ and $20.000 \mathrm{ppm}$ in minutes 0, 15, 30, 45, 60, 75 and 90: (a) PC1 vs PC2; (b) PC1 vs PC3; (3) PC2 vs PC3

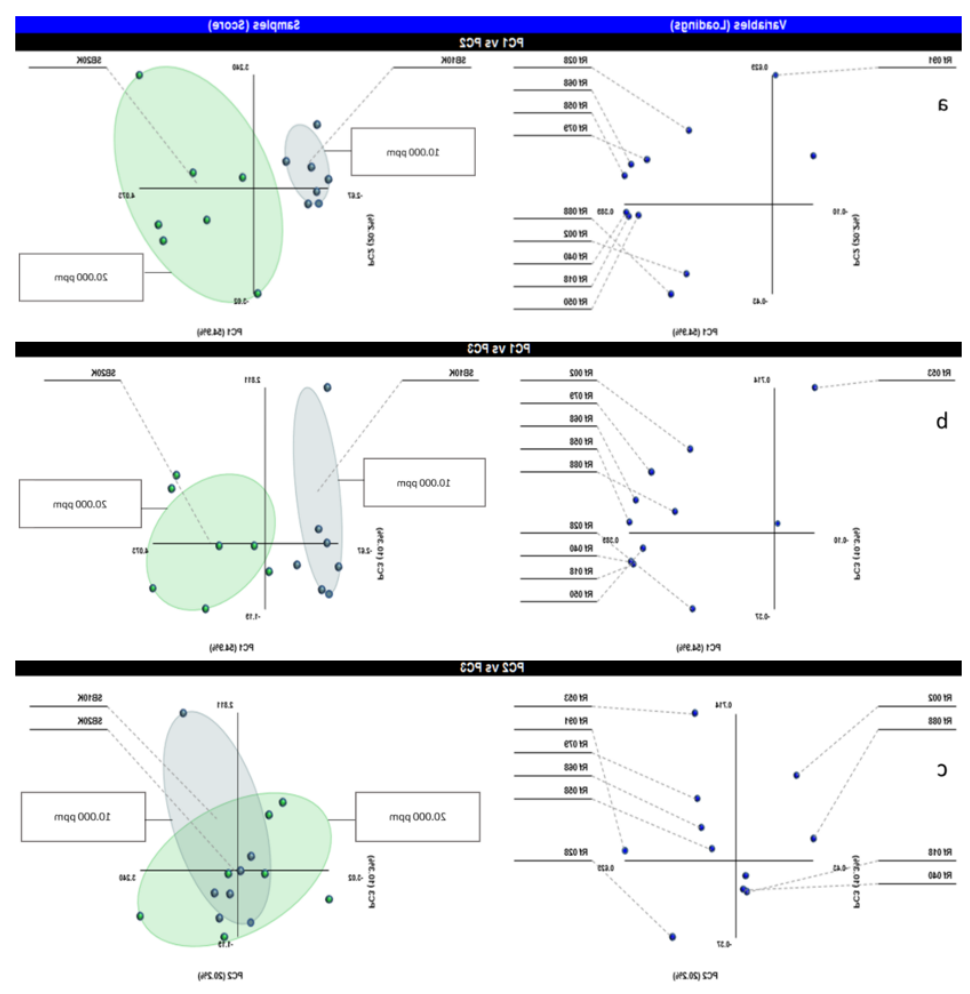

Figure 2. PCA profile (in principal component/PC) for stability test (on HPTLC plate) between concentration 10.000 ppm and 20.000 ppm in minutes 0, 15, 30, 45, 60, 75 and 90: (a) PC1 vs PC2; (b) PC1 vs PC3; (3) PC2 vs PC3 


\section{Roihatul Mutiah}

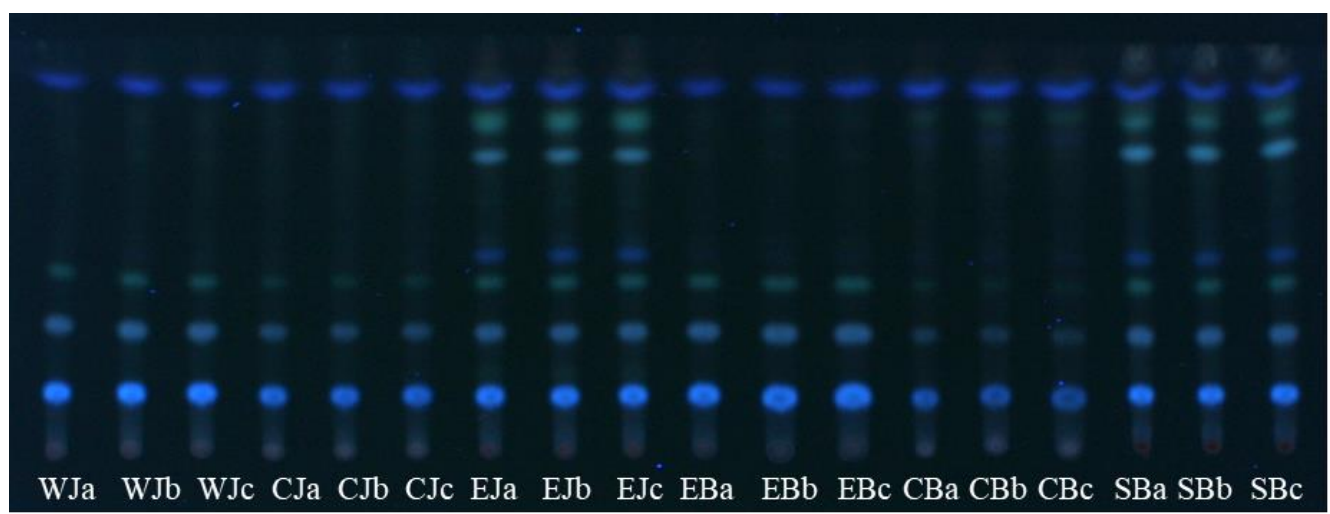

Figure 3. Metabolite fingerprinting of E. palmifolia ethanol extract, the WJa-WJc (West Java) sample, CJa-CJc (Central Java), EJa-EJc (East Java), EBa-EBc (East Borneo), CBa-CBc (Central Borneo), SBa-SBc (South Borneo) were eluted with the mobile phase chloroform: metanol $(80: 20 \mathrm{v} / \mathrm{v})$ and derivatized using $10 \%$ $\mathrm{H}_{2} \mathrm{SO}_{4}$ on $366 \mathrm{~nm} \mathrm{UV}$ with three times replication.

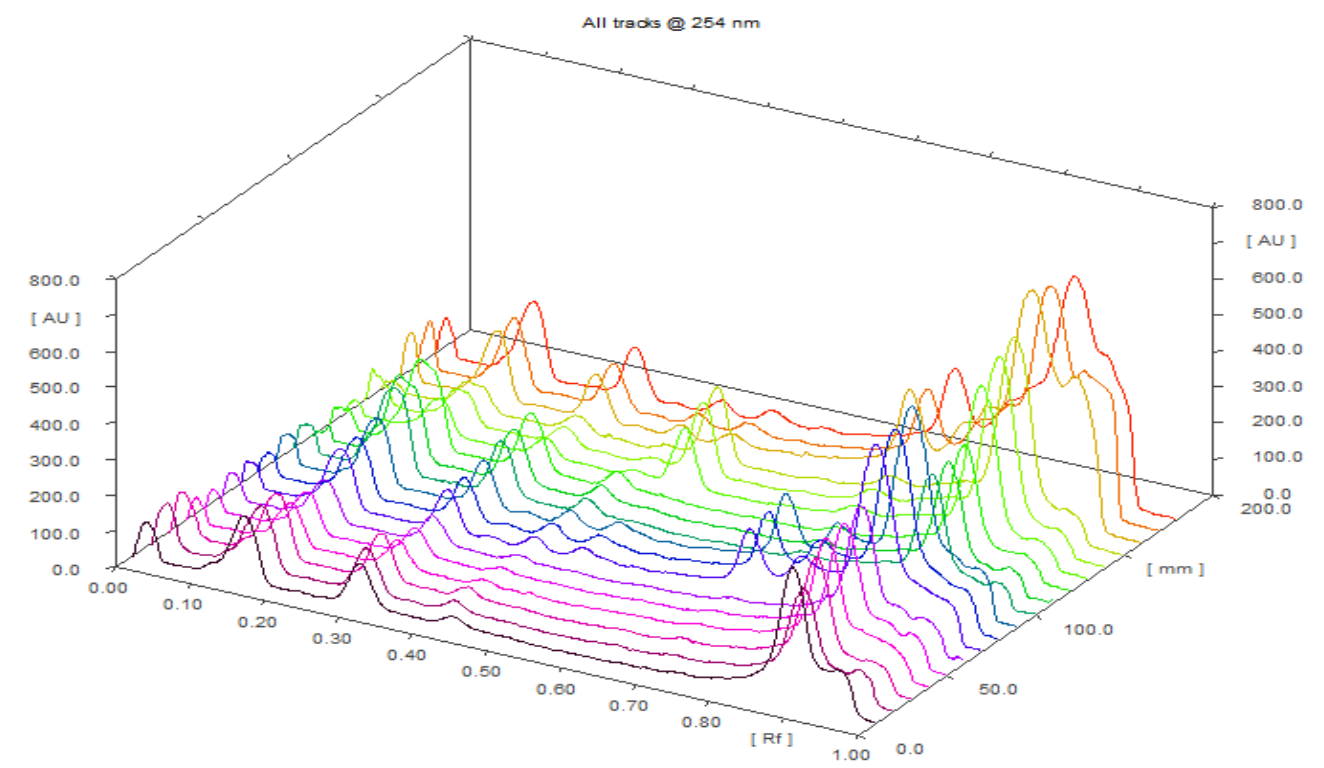

Figure 4. Densitogram of HPTLC using TLC Scanner-4 (Camag) on 254nm UV, with a scan speed 20mm/s, the data resolution $100 \mu \mathrm{m} / \mathrm{step}$, the first track position X $10.0 \mathrm{~mm}$, distance between the track $10.0 \mathrm{~mm}$, the position started from scan Y $15.0 \mathrm{~mm}$ and the last scan $Y 90.0 \mathrm{~mm}$

\section{Metabolite fingerprinting of E. palmifolia extract}

Metabolite fingerprinting from eighteen samples of E. palmifolia extracts obtained from six different locations i.e. West Java (WJ1a-WJ1c), Central Java (CJ1a -CJ1c), East Java (EJ1a-EJ1c), East Borneo (EB1a-EB1c), Central Borneo (CB1a-CB1c) and South Borneo (SB1a-SB1c) were analyzed with a normal phase HPTLCdensitometry. The stationary phase used was an 20x10 cm F 254 silica gel 60 HPTLC plate and the selected mobile phase was chloroform: methanol $(80: 20 \mathrm{v} / \mathrm{v})$ with extract concentration of $10.000 \mathrm{ppm}$ in ethanol.

The metabolites profiles of E. palmifolia extract from six different locations were similar although they grew from different environments (Figure 3). There were 145 metabolites detected using HPTLC-densitometry (Figure 4) and each region averagely contained eight metabolites. 


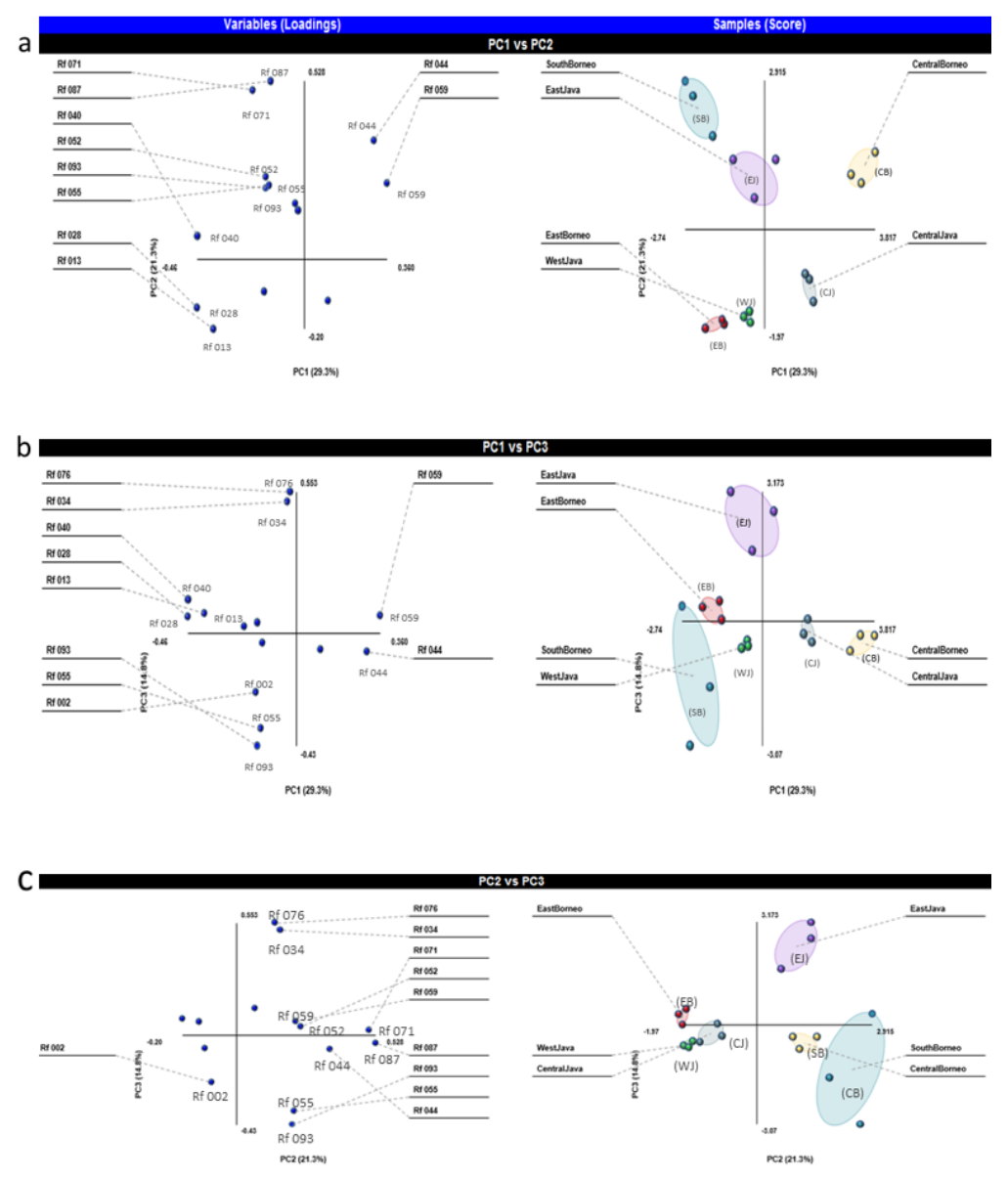

Figure 5. Metabolite fingerprinting of E. palmifolia using Principal Component Analysis (PCA) between Loading Plot (left) and Score Plot (right) explained variants PC1 (29.3\%), PC2 (21.3\%), PC3 (14.8\%) and total variants explained by three principle components were $65.4 \%$.

The retention factor (Rf) values found in each region showed similarities. The same $\mathrm{Rf}$ values found in all regions were $0.13,0.28,0.40$, 0.71 and 0.87 . The results of this metabolite fingerprinting of E. palmifolia extract could be proposed as a candidate of analytical marker compounds of this plant.

\section{Principal component analysis (PCA)}

The results of metabolite fingerprinting were analyzed using PCA. PCA showed the visualization of the score plot (right) and the loading plot (left). Score plots described the characteristics of the sample, whereas the loading plot described the relationship (correlation) between the variables in each component. PCA score plot and loading plot explained variants PC 1 (29.3\%), PC 2 (21.3\%), PC 3 (14.8\%) and total variants explained by the three principal components were $65.4 \%$. Visualization of PCA results showed that three significant metabolites influenced clusters formation because they appeared on each PC, both PC1, PC2, and PC3 (Figure 5). The significant metabolites were found on Rf values of $0.44,0.55$ and 0.59 .

There were two clusters formed i.e. (I) EB, CJ, WJ and (II) EJ, SB, CB (Figure 5). The metabolites of E. palmifolia originated from EB, CJ and WJ showed similarities among them as well as those from EJ, SB, and CB. To confirm the clusters formed in PCA, HCA analysis was also carried out.

\section{Hierarchical clustering analysis (HCA)}

The results of HCA showed characteristics that were close among samples from West Java (green), East Borneo (red), Central Java (grey), 
South Borneo (blue), Central Borneo (yellow) and East Java (purple). It could be concluded that all samples taken from six different locations were similar and located in one cluster (Figure 6).

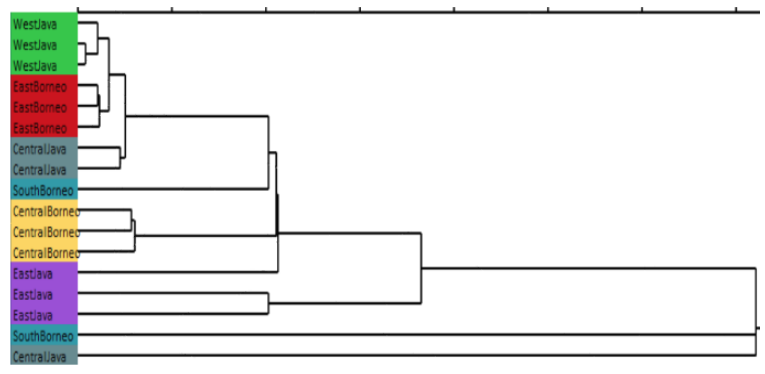

Figure 6. Dendrogram of Hierarchical Clustering Analysis (HCA) that showed the similarity of E. palmifolia from West Java (Green), East Borneo (Red), Central Java (Grey), Central Borneo (Yellow), East Java (Purple) and South Borneo (Blue)

The HCA results showed that the metabolite fingerprinting of East Borneo was similar to West Java and Central Java. Central Borneo has similarities with South Borneo and East Java. The contents of these metabolites were influenced by two factors i.e. internal factors and external factors (Heuberger, et al. 2014). Internal factors that influenced the composition of the compound included genetic and physiological variations, whereas external factors are factors such as geographical conditions (altitude), climate, humidity, light intensity, temperature, nutrient intake and radiation (Verma and Shukla, 2015).

\section{Cytotoxic test of E. palmifolia extract}

The cytotoxic test aimed to determine the anticancer potency from six different regions in Indonesia. The cytotoxic test was carried out using the MTT assay method on WiDr cells. WiDr cells were treated using a $96 \%$ ethanol extract of E. palmifolia bulb with concentration series $(\mu \mathrm{g} / \mathrm{mL})$ of $125 ; 62.5 ; 31.25 ; 15,625$ and 7.8125 .

In this experiment, the percentage of cell viability was lower with increasing extract dose and on the other hand it was higher with decreasing dose (Muti'ah et al., 2018) (Figure 7). This showed that there was an existence of a dosedependent phenomenon between the concentration and viability of living cells. Then, the percentages of cell viability were converted using probit analysis to obtain $\mathrm{IC}_{50}$. The results of probit analysis showed that there were differences in $\mathrm{IC}_{50}$ of E. palmifolia extracts from six different locations. The $\mathrm{IC}_{50}$ values $(\mu \mathrm{g} / \mathrm{mL})$ were 86.98 (East Jawa), 104.52 (Central Borneo), 133.23 (East Borneo), 159.07 (West Java), 269.80 (South Borneo) and 272.55 (Central Java). Dayak onion extract originating from the East Java region showed the highest cytotoxic effect on WiDr cells (the lowest $\mathrm{IC}_{50}$ ) than other extracts and it also showed potent activity as an anticancer with an $\mathrm{IC}_{50}$ value $<100 \mu \mathrm{g} / \mathrm{mL}$ (Prayong et al., 2008).

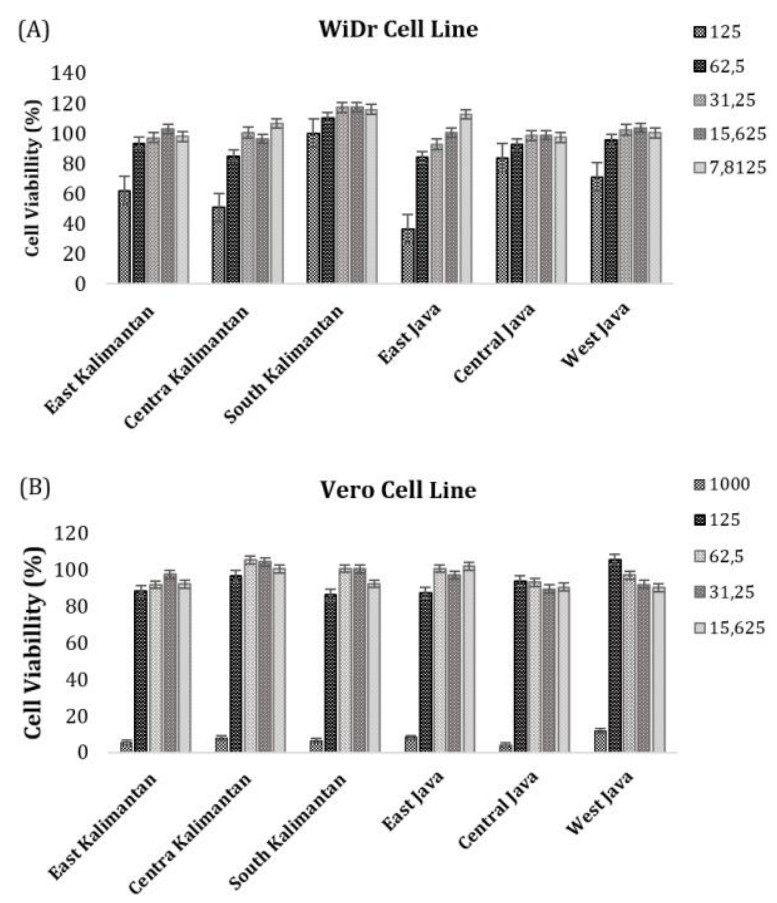

Figure 7 . The percentage of viability cell $( \pm S D)$ on colon cancer cell WiDr (A) and normal/vero cell (B) with a series dose of $96 \%$ E. palmifolia extract from six different regions.

In the development of an anticancer drug, selectivity index (SI) is very important to obtain a profile of anticancer activity of an extract on inhibiting cancer cell proliferation without damaging the normal cell. It is termed "selective" if the value of the selectivity index (SI) is $>3$ (Sutejo et al., 2016). The SI value was used to measure the safety of an anticancer drug (Dewi et al., 2015). The results showed that the SI value of E. palmifolia extracts were mostly selective except for exctract originated from South Borneo and Central Java. However, E. palmifolia extracts originating from East Java and Central Borneo showed a higher selectivity value compared to cisplatin as standard (Table II). 
Table II. IC 50 Analysis of Sample on WiDr Cells

\begin{tabular}{lcccl}
\hline Sample & IC $_{\mathbf{5 0}}$ WiDr Cells $(\boldsymbol{\mu g} / \mathbf{m L}) \pm$ SD $^{*}$ & IC $_{50}$ vero Cells $(\boldsymbol{\mu g} / \mathbf{m L}) \pm$ SD $^{*}$ & SI & Interpretation \\
\hline East Borneo & $133.23 \pm 12.53$ & $414.65 \pm 46.41$ & 3.1 Selective \\
South Borneo & $269.80 \pm 34.42$ & $446.49 \pm 5.37$ & 1.7 Non-Selective \\
Central Borneo & $104.52 \pm 12.09$ & $528.77 \pm 41.49$ & 5.1 Selective \\
East Java & $86.98 \pm 4.62$ & $476.87 \pm 32.44$ & 5.5 Selective \\
West Java & $159.07 \pm 12.28$ & $519.70 \pm 2,00$ & 3.3 Selective \\
Central Java & $272,55 \pm 42.47$ & $393.16 \pm 24.66$ & 1.4 Non-Selective \\
Cisplatin & $47.16 \pm 2.22$ & $232.35 \pm 43.00$ & 4.9 Selective \\
\hline
\end{tabular}

*SD $=$ Standard Deviation from 3 times replication

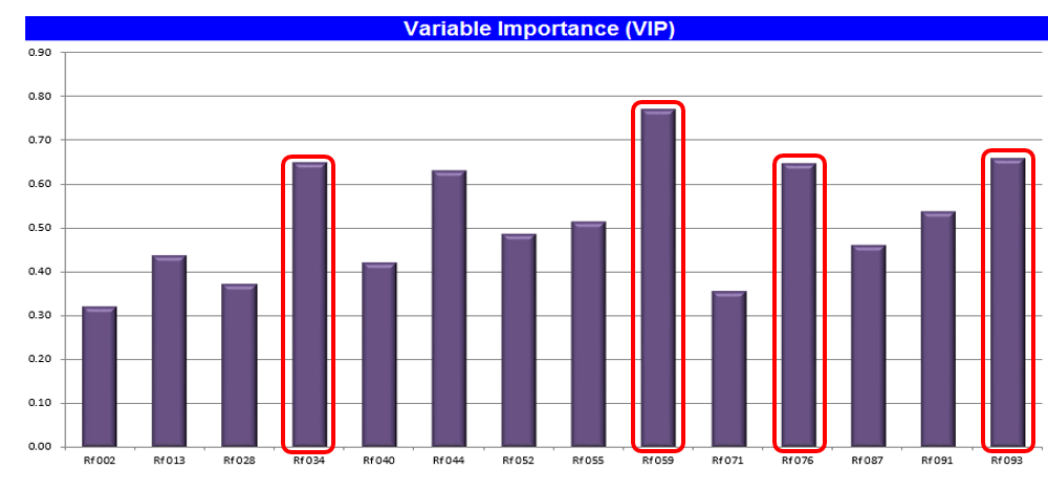

Figure 8. Partial Least Square (PLS) of metabolite fingerprinting and anticancer activity. Variable Importance (VIP) was the metabolite responsible for anticancer activity

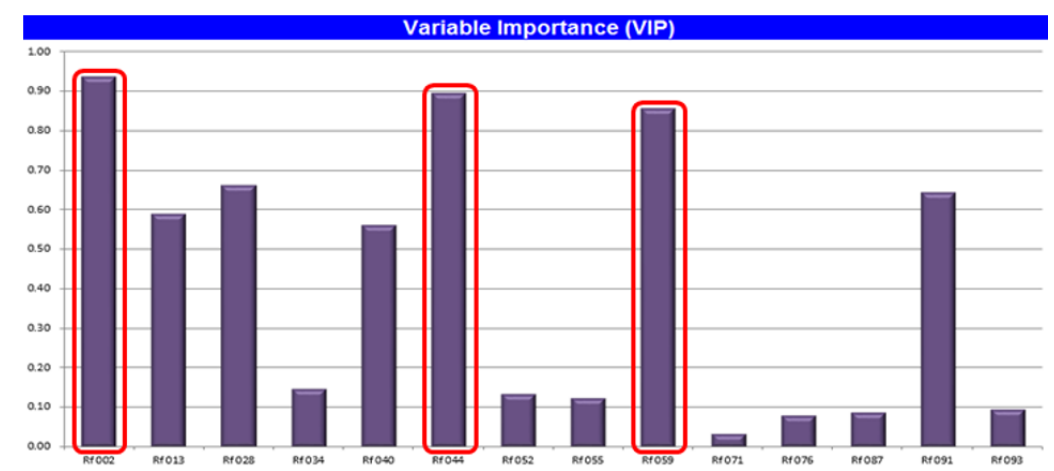

Figure 9. Partial Least Square (PLS) of metabolite fingerprinting and toxicity profiles. Variable Importance (VIP) was the metabolite responsible for toxicity activity.

\section{Correlation between metabolite fingerprinting and in vitro anticancer activity}

Anticancer activity of E. palmifolia from six different locations showed different activity eventhough they were originated from plants of the same type. Environmental factors might affect the content of secondary metabolites quantitatively and qualitatively so that their bioactivity might also vary. This could cause differences in the quality of phytomedicine (Kim et al., 2011). In this study, the Partial Least Square (PLS) analysis was conducted to determine the correlation of anticancer activity with metabolite fingerprints from six different regions.

The highest value of Variable Importance (VIP) was the metabolite responsible for the 
anticancer activity (Figure 8). It could be seen that there were four highest Rf values: Rf 0.59 owned by East Java and Central Borneo, Rf 0.93 owned by all locations, Rf 0.34 owned only in East Java, and Rf 0.76 owned by Central and East Java.

\section{Correlation between metabolite fingerprinting and in vitro toxicity}

The results of PLS analysis of metabolite fingerprinting and in vitro toxicity of E. palmifolia extract were known according to the Variable Importance (VIP). The higher the VIP value, the greater the potency to cause toxicity. The metabolites responsible for the toxicity were metabolites with Rf 0.02 owned by extracts from all locations, Rf 0.44 owned by extracts from East Java, Central Borneo and South Borneo, and Rf 0.59 owned by extracts from East Java and Central Borneo (Figure 9). In the PLS analysis results of metabolite fingerprinting and toxicity, there were similarities to the results of PLS metabolite fingerprinting and anticancer activity i.e. Rf 0.44 and $\mathrm{Rf} 0.59$ as metabolite responsible for anticancer activity and toxicity.

\section{CONCLUSION}

E. palmifolia from six different locations showed differences in metabolite fingerprint, activity profile, and toxicity profile. There were five metabolites that were used as candidates of analytical markers i.e. compound with $\mathrm{Rf} 0.13$, Rf 0.28 , Rf 0.40 , Rf 0.71 and $\mathrm{Rf} 0.80$ for this plant because they were found in all locations. Metabolites responsible for anticancer activity were found in metabolites with $\mathrm{Rf} 0.34,0.59$, Rf 0.76 and Rf 0.93 that could be proposed as positive markers compound for anticancer activity. Besides that, metabolites responsible for toxicity were metabolites with Rf $0.02,0.44$, and 0.59 that could be proposed as negative markers compound. E. palmifolia from East Java had the lowest $\mathrm{IC}_{50}$ $(86.98 \pm 4.62 \mu \mathrm{g} / \mathrm{mL})$ and a higher SI value (5.5).

\section{ACKNOWLEDGMENT}

We would like to say thank you to the Ministry of Religion Research Grant for the International Applied Global Research Scheme with number 4670 in 2018 on behalf of Retno Susilowati and Roihatul Mutiah.

\section{REFERENCES}

Indonesia National Agency of Drug and Food Control. 2005. Peraturan Kepala Badan Pengawas Obat dan Makanan Republik
Indonesia Nomor: HK.00.05.41.1384 tentang Kriteria dan Tata Laksana Pendaftaran Obat Tradisional, Obat Herbal Terstandar dan Fitofarmaka. Jakarta; Badan Pengawas Obat dan Makanan Republik Indonesia.

Canas RA., Canales J., Muñoz-Hernández C., Granados JM., and Ávila CLM.,. 2015. Understanding Developmental and Adaptive Cues In Pine Through Metabolite Profiling and Co-Expression Network Analysis. 66:3113-3127.

Chahar MK., Sharna N., Dobhal NP. and Joshi YC., 2011. Flavonoids: A versatile source of anticancer drugs. Pharmacogn Rev. 5: 1-12

Dewi NR., Kuncoro H., and Rijai L., 2015. Potensi Sitotoksik Ekstrak Air Daun Sirih Hitam (Piper sp.) . Jurnal sains dan Kesehatan. 1 (1)

Dhalwal K., Shinde VM., Namdeo AG. and Mahadik KR., 2008. Antioxidant Profile and HPTLCDensitometric Analysis of Umbelliferone and Psoralen in Aegle Marmelos. Pharmaceutical Biology. 46: 266-72.

Febriyanti AP., Iswarin SJ. and Pariwara PW., 2016. Identifikasi dan Eksplorasi Etnomedisina pada Suku Samin di Kabupaten Bojonegoro, Jawa Timur. J. Pharm. Med. Sciences. 1: 69-74.

Fiehn 0. 2002. Metabolomics-The Link between Genotypes to Phenotypes. Plant Molecular Biology. 48: 155-71.

Fitri Y., Rosidah Suwarso E., 2014. Effects of Inhibition Cell Cycle and Apoptosis of Sabrang Onion extract (Eleutherine bulbosa (Mill.) Urb.) on Breast Cancer Cells. 6.

Huberger AL., Corey D., Broeckling KR., Kirkpatrick JE., Penni., 2014. Application of Non Targeted Metabolite Profiling to Discover Novel Marker of Quality Traits in a Advanced Population of Marting Barley. Plant Biotechnology Journal. 12:147-160. Id Climate Data, 8 Januari 2017. Data climate. www.id.climate-data.org

Indah YN., Diah IP., Suwidji W., Bambang EWP. and Gunawan I., 2015. Metabolite Profiling of Justicia gendarussa Burm f. Leaves Using UPLC-UHR-QTOF-MS.

Scientia Pharmaceutica. 83:489-500.

Kim EJ., Kown J., Park SH., Park C., Seo YB. and Shin HK., 2011. Metabolite Profillingof Angelica Gigas From Diferen Geographical OriginUsing H-NMR and UPLC-MS Analyses. 59: 8806-8815.

Kuntorini E. and Astuti M., 2010. Penentuan Aktivitas Antioksidan Ekstrak Etanol Bulbus 
Bawang Dayak (Eleutherine americana Merr.). Sains dan Terapan Kimia. 4: 15-22.

Li X., Ohtsuki T., Koyano T., Kowithayakorn T. and Ishibashi M., 2008. New Wnt/ $\beta$-Catenin Signaling Inhibitors Isolated from Eleutherine palmifolia. Chemistry An Asian Journal. 4: 540-547.

Maharani S., 2009. Mengenal 13 Jenis Kanker dan Pengobatannya. Jogjakarta: Katahati.

Mutiah R. and Aty W., Sukardiman S., 2017. Ethyl Acetate Fraction of Calotropis Gigantea Roots Induce Apoptosis Through Increased G2/M And Increased Expression Of Caspase8 In Colon Cancer Widr Cell Line. Journal of Applied Pharmaceutical Science. 7: 197201.

Mutiah R., Aty W. and Sukardiman S., 2018. Calotropis gigantea Leaf Extract Increases the Efficacy of 5-Fluorouracil and Decreases the Efficacy of Doxorubicin in Widr Colon Cancer Cell Culture. Journal of Applied Pharmaceutical Science. 8: 051-056.

Patel NG., Patel KG., Patel KV. and Gandhi TR. 2015. Validated HPTLC Method for Quantification of Luteolin and Apigenin in Premna Mucronata Roxb., Verbenaceae. Advances in Pharmacological Sciences. 2015: 1-7.

Prayong P., Barusrux S. and Weerapreeyakul N., 2008. Cytotoxic Activity Screening of Some Indigenous Thai Plants. Fitoterapia. 79: 598601.
Ravichandran V., S Shalini., M Sudram K. and Rajak H., 2010. Validation of Analytical MethodsStrategies \& Importance. Int J Pharmacy and Pharmaceutical Sciences. 2: 18-22.

Ren W., Qiao Z., Wang H., Zhu L. and Zhan L., 2003. Flavonoids: Promising Anticancer Agents. 23: 519-534.

Sutejo IR., Putri H. and Meiyanto E., 2016. The Selectivity of Ethanolic Extract of Buah Makassar (Brucea javanica) on In Vitro Study of Metastatic Breast Cancer. Journal of Agromedicine and Medical Sciences. 2.

Taufik I., 2017, Profil Metabolit Kulit Batang Artocarpus champeden Spreng Secara HPTLC Densitometri serta Hubungannya dengan Antimalaria dan Toksisitas in vitro, Tesis, Program Studi Magister Ilmu Farmasi Universitas Airlangga, Surabaya.

Verma N. and Shukla S., 2015. Impact of Various Factors Responsible for Fluctuation in Plant Secondary Metabolites. J. Applied Research on Medicinal and Aromatic Plants 2: 105-13.

Wolfender JL., Marti G., Thomas A., and Bertrand S., 2015. Current Approaches and Challenges for the Metabolite Profiling of Complex Natural Extracts. Journal of Chromatography A 1382:136-64.

Yuwono M. and Indriyanto G. 2005. Validation of Chromatograhic Method of Analysis. Profiles of Drug Subtances, Excipients and Related Methofology. 32: 243-259. 